\title{
Antibacterial Activity for Acne Treatment through Medicinal Plants Extracts: Novel Alternative Therapies for Acne
}

\author{
Muna Jalal Ali' ${ }^{1 *}$ (D), Rasha Fadhel Obaid ${ }^{2}$ and Rana Fadhil Obaid ${ }^{3}$ \\ ${ }^{1}$ Department of Medical Laboratory Technique, Al-Haweeja Technical Institute, Northern Technical University, \\ Mosul, Iraq. ${ }^{2}$ Department of anesthesia techniques, Al-Mustaqbal University College, Babylon, Iraq. ${ }^{3}$ Department \\ of medical microbiology, Faculty of medicine, University of Kufa, Najaf, Iraq.
}

\begin{abstract}
Acne vulgaris is a chronic skin infection affecting the majority of adults. There are several internal and external factors responsible for this infection. The present study emphasizes the screening and combinations of medicinal plants extracts against acne-causing bacteria and antibacterial activity of these plant extracts. Antibacterial activities of three solvents extracts of Camellia sinensis, Azadirachta indica, and Cassia acutifolia was carried out using disc diffusion method against Propionibacterium acnes, Staphylococcus aureus, Staphylococcus epidermidis, Pseudomonas aeruginosa, Escherichia coli and Bacillus subtilis. The results revealed that different plant extracts showed noticeable activity against different test organisms. The acetone extract of combination $A(C / A)$ showed the higher mean of antibacterial susceptibility against six bacterial strain with synergistic effect by $20.33 \mathrm{~mm}$ than other combinations when combination $A$ (C/A) was added. The antimicrobial susceptibility of combination $A(C / A)$ was higher than combination group at concentration of $10^{-2}$ with $95 \%$ confidence interval. The present study concluded that the acetonic extract of C/A was the best antibacterial agent/candidate to treat acne vulgaris disease. Further trials might confirm its best possible doses for prescription to the dermatologists, physicians and clinicians in the field.
\end{abstract}

Keywords: Antibacterial activity, plant extracts, acne vulgaris, bacterial strains.

\footnotetext{
*Correspondence: munajalal2@gmail.com

(Received: 18 March 2019; accepted: 19 May 2019)

Citation: Muna Jalal Ali, Rasha Fadhel Obaid and Rana Fadhil Obaid, Antibacterial Activity for Acne Treatment through Medicinal Plants Extracts: Novel Alternative Therapies for Acne, J Pure App/ Microbiol., 2019; 13(2):1245-1250. doi: 10.22207/JPAM.13.2.66

(C) The Author(s) 2019. Open Access. This article is distributed under the terms of the Creative Commons Attribution 4.0 International License which permits unrestricted use, sharing, distribution, and reproduction in any medium, provided you give appropriate credit to the original author(s) and the source, provide a link to the Creative Commons license, and indicate if changes were made.
} 


\section{INTRODUCTION}

Acne is one of the commonest skin unrest, for which dermatologists are still struggling since years to treat it successfully. It fundamentally affects teenagers, although it may present at any age of life. It is almost a cosmopolitan disease occurring in all races and affecting $94 \%$ of 16 -yearold boys and $82 \%$ of 16 -year-old girls to some degree(Vora et al., 2017). The incidence of severity of acne, peaks at $41 \%$ in 13-18-year-old girls and $35 \%$ in boys aged $17-20$ year (Kim et al., 2017). Acne by definition is a multi-factorial chronic inflammatory disease of pilosebaceous units. It affects the skin of the face, neck and upper trunk. These special sebaceous follicles have capacious follicular channels and voluminous, multi-acne sebaceous glands. Acne develops when these specialized follicles undergo pathogenic change that results in the formation of non-inflammatory lesions and inflammatory lesions (Choi et al., 2011).

In this regard, the Staphylococcus epidermidis considered as the major skin bacteria that causes the formation of acne. Propioni-bacterium acnes, a gram positive and an anaerobic pathogen, plays an essential role in the pathogenesis of acne. It is involved in the development of inflammatory acne by its might to activate complements and by its ability to metabolize sebaceous triglycerides into fatty acids, which chemotactically attract neutrophils (Vora et al., 2017). In addition, Staphylococcus epidermidis, anaerobic organism, is usually involved in super facial infections within the sebaceous unit (Vora et al., 2017).

On the other hand, the medicinal plants have attracted increasing interest because of their antimicrobial susceptibility against pathogenic oral microorganisms. Plants that are used for traditional medicine contain a wide range of substances that can be used to treat chronic and infectious diseases (Ali et al., 2016). Medicinal plants exploration has become important in the discovery of bioactive natural substances capable of inhibiting the mechanisms of different microbials. According to the World Health Organization (Who) report on antimicrobial resistance in 2014, overcoming the antibiotic resistance is the major issue to the WHO for the next millennium. Screening of plants for antimicrobial agents has gained much importance because $\mathrm{WHO}$ is encouraging and promoting in the development and utilization of medicinal plants resources in the traditional system of medicine. Accordingly, the last decade witnessed an increase in the investigation of plants as a source of human infectious disease management (Mickymaray et al., 2016). According to the WHO about $71 \%-94 \%$ of the world's population in developing countries relies mainly on indigenous medicinal plants for their primary health care. Traditional medicine has not only gained in popularity and approval, but it is sometimes the only system available in many rural areas. Furthermore, the use of medicinal plants to treat skin infections is very common in many rural areas all over the world (Gupta et al., 2017).

Therefore, the present study was designed to determine the antibacterial activity of different medicinal plants extracts used for the treatment of acne.

\section{METHODOLOGY}

Assay for antibacterial activity by disc diffusion method

The test organisms used in this study were procured from Faculty of Industrial science and technology (FIST), Pahang. Malaysia, viz., Propionibacterium acnes, Staphylococcus aureus, Staphylococcus epidermidis, Pseudomonas aeruginosa, Escherichia coli and Bacillus subtilis was used.

\section{Medicinal plants extraction and investigation} Medicinal plants used

Preparation of extracts: The selected three commercial leaves of plants used in the study, namely, Camellia sinensis(Cs), Azadirachta indica (Ai), and Cassia acutifolia (Sa), were purchased from the market at kirkuk area, Iraq.

\section{Preparation of plants extracts}

The three plant parts were crushed using a blender and then sieved to obtain fine powders. Approximately $10 \mathrm{~g}$ of the powdered plants were soaked in $100 \mathrm{ml}$ of four different solvents $(95 \%$ ethanol, hot water, and acetone) kept at room temperature for $24 \mathrm{~h}$, and the suspension was then filtered through a Whatman No.1 filter paper. The filtrates were evaporated to $5 \mathrm{ml}$ the final concentration was $10 \%(\mathrm{~g} / \mathrm{v})$, using a rotary evaporator (BUCHI, Rotavapor R-3 Vacuum pump $V$-700), according to the modified method of (Gahlaut et al., 2013). The extracts were stored 
in sterile bottles at $4^{\circ} \mathrm{C}$ until further use. Filter paper discs of $6 \mathrm{~mm}$ diameter were prepared using Whatman No. 1, UV sterilized, and loaded with $25 \mu$ l plant extracts, left to dry, and then used an antibacterial screening test (Ali et al., 2015).

\section{Plants extract against bacterial isolates}

Muller-Hinton agar medium was used for the antimicrobial susceptibility. The plants extract discs from previously prepared solvents were allowed to set onto the inoculated agar surface. Inoculum from primary culture plates were prepared, inoculating into a replicated plate, and incubation at $37^{\circ} \mathrm{C}$ for $24 \mathrm{~h}$. After the incubation period, each plate was observed, and the inhibition zone of all isolates were recorded in millimetre $(\mathrm{mm})$ calculated and represented as previously mentioned (Mukhtar et al., 2012). The density of each bacterial suspension was adjusted using $0.5 \mathrm{McF}$ arland as a standard. Control discs for different solvents were used.

\section{Combination of plant extracts}

The combination of plant extracts obtained using the three different solvents was studied at a ratio of $1: 1$ (v:v). the two combination groups, $A$ and $B$, were prepared using the combination of two plant extracts together $(A)$ $(C / A, C / S, A / S)$ and all tree extracts $(B)(C / A / S)$, respectively. All combinations were tested for antimicrobial susceptibility against bacterial isolates as previously mentioned.

\section{Determination of minimum inhibitory concentration}

The minimum inhibitory concentration of combination prepared of 10 different dilutions from $10^{-1}-10^{-10}$, the bacterial suspension was adjusted using a 0.5 McFarland standard at $600 \mathrm{~nm}$. The tube dilution assay with slight modification (Donaldson et al., 2005) was selected as the method for determining the minimum inhibitory concentration. Serial dilutions were used to prepare a series of ten tubes. The initial tube was filled with $200 \mu \mathrm{l}(\mathrm{v} / \mathrm{v})$ of a highest combination of plant extract were added. The mixture was vortexed and $100 \mu \mathrm{l}$ was removed and placed into a second tube containing $900 \mu$ l of acetone. This process was repeated to create ten dilutions with concentrations of $10^{-1}-10^{-10}$. Each concentration was streaked onto Mueller-Hinton agar media; acetone was used as a control. Bacterial plates were incubated for 24 hours at $37^{\circ} \mathrm{C}$ and the concentration that inhibited the bacteria was identified and the resultant MIC was recorded in $(\mathrm{mm})$ with MIC being defined as the lowest concentration of combination for inhibiting the growth of the microorganism (Mccutcheon et al., 1994). The acetone disc was used as control and the experimental assays were replicated three times.

\section{Statistical analysis}

Statistical analyses were performed using ANOVA for data on disc diffusion assays, to test the antibacterial activity profile of isolates within medicinal plant extracts on the zone of inhibition using software Minitab 17. All antibacterial activity data were determined in diameter $(\mathrm{mm})$, calculated and represented in this paper as antibacterial activity mean of inhibition zone against all the bacterial isolates under study.

\section{RESULTS AND DISCUSSION}

Antibacterial susceptibility of medicinal plants against bacterial isolates

The acetone extracts of Camellia sinensis, Azadirachta indica and Cassia acutifolia, showed higher antibacterial susceptibility of the mean of inhibition zone against bacterial isolates, reaching to $34.67,18.76$, and $12.76 \mathrm{~mm}$, respectively. By comparison, the antimicrobial susceptibility was exhibited by the $95 \%$ ethanolic and the aqueous extracts of medicinal plants did not exhibit an inhibitory effect against the tested microorganisms as shown in Figures 1.a,b,c and

Table 1. Screening of antibacterial susceptibility of Camellia sinensis extracts using three different solvents against bacterial isolates

\begin{tabular}{lccc}
\hline $\begin{array}{l}\text { Bacterial } \\
\text { strains }\end{array}$ & $\begin{array}{c}\text { Ethanol } \\
\text { Mean } \pm S D^{*}\end{array}$ & $\begin{array}{c}\text { Hot water } \\
\text { Mean } \pm S D\end{array}$ & $\begin{array}{c}\text { Acetone } \\
\text { Mean } \pm S D\end{array}$ \\
\hline $\begin{array}{l}\text { P. acnes } \\
\text { S. aureus }\end{array}$ & $13.67 \pm 0.47$ & $8.67 \pm 0.47$ & $16.33 \pm 0.47$ \\
S. & $15.63 \pm 0.47$ & $8.67 \pm 0.47$ & $21.67 \pm 0.47$ \\
epidermidis & & $9.67 \pm 0.47$ & $21.33 \pm 0.47$ \\
$\begin{array}{l}\text { P. } \\
\text { aeruginosa }\end{array}$ & $8.67 \pm 0.47$ & $8.67 \pm 0.47$ & $30.33 \pm 0.47$ \\
$\begin{array}{l}\text { E. coli } \\
\text { B. subtilis }\end{array}$ & $10.33 \pm 0.47$ & $9.33 \pm 0.47$ & $30.33 \pm 0.47$ \\
\end{tabular}

Results were expressed as mean $\pm S D, n=3$. SD* standard deviation 
Tables 1-3. The acetonic extracts of Camellia sinensis, Azadirachtaindica exhibited effective antibacterial preparation against bacterial isolates. These extracts were not harmful when consumed in products and used as agents that inhibit the growth of bacteria. The hot water extracts of three medicinal plants showed low antibacterial susceptibility, which may be due to the polarity of compounds; most antibacterial agents are extracted more effectively by organic solvents than by aqueous extraction (Aneja et al., 2010). The results in current study were contrary to those in the study of Al-Emran et al. 2011 who reported that the results depict that leaf extracts of Azadirachtaindica could be used as a potential source of antimicrobial agents against the bacterial strains tested (Abdullah-Al-Emran et al., 2011). These results were similar to the finding of Gupta and Kumar (2017), who investigated that the antimicrobial susceptibility of camellia sinensis

Table 2. Screening of antibacterial susceptibility of Azadirachta indica extracts using three different solvents against bacterial isolates

\begin{tabular}{lccc}
\hline $\begin{array}{l}\text { Bacterial } \\
\text { strains }\end{array}$ & $\begin{array}{c}\text { Ethanol } \\
\text { Mean } \pm S D *\end{array}$ & $\begin{array}{c}\text { Hot water } \\
\text { Mean } \pm \text { SD }\end{array}$ & $\begin{array}{c}\text { Acetone } \\
\text { Mean } \pm S D\end{array}$ \\
\hline $\begin{array}{l}\text { P. acnes } \\
\text { S. aureus }\end{array}$ & $12.33 \pm 0.47$ & $8.67 \pm 0.47$ & $18.67 \pm 0.47$ \\
S. & $12.33 \pm 0.47$ & $8.67 \pm 0.47$ & $12.33 \pm 0.47$ \\
epidermidis & & $9.67 \pm 0.47$ & $11.33 \pm 0.47$ \\
$P$. & $10.33 \pm 0.47$ & $8.67 \pm 0.47$ & $13.33 \pm 0.47$ \\
$\begin{array}{l}\text { aeruginosa } \\
\text { E. coli }\end{array}$ & $11.33 \pm 0.47$ & $9.33 \pm 0.47$ & $14.33 \pm 0.47$ \\
B. subtilis & $0.00 \pm 0.00$ & $8.67 \pm 0.47$ & $13.33 \pm 0.47$ \\
\hline
\end{tabular}

and Terminalia arjuna are traditional medicinal plants and represent rich source of compounds possessing antimicrobial properties (Gupta et al., 2017).

\section{Combination of plant extracts}

The results of antimicrobial susceptibility profile of four combinations prepared, with the use of acetone plant extracts to obtain medicinal plants extracts, are shown in Table 4. The acetone extract of combination $A(C / A)$ showed the higher mean of antibacterial susceptibility against six bacterial strains with synergistic effect by $20.33 \mathrm{~mm}$ than other combinations, followed by acetone extract of combination $B(C / A / S)$, with 13.67 .

These results were similar to the finding of Naveed et al. (2013), who reported that most of the essential oils of Cuminum cyminum, Cinnamom umverum, Amomum subulatum and Syzygium aromaticum. Their antibacterial activities were investigated by minimum inhibitory concentrations

Table 3. Screening of antibacterial susceptibility of Cassia acutifolia extracts using three different solvents against bacterial isolates

\begin{tabular}{lccc}
\hline $\begin{array}{l}\text { Bacterial } \\
\text { strains }\end{array}$ & $\begin{array}{c}\text { Ethanol } \\
\text { Mean } \pm S D\end{array}$ & $\begin{array}{c}\text { Hot water } \\
\text { Mean } \pm S D\end{array}$ & $\begin{array}{c}\text { Acetone } \\
\text { Mean } \pm S D\end{array}$ \\
\hline $\begin{array}{l}\text { P. acnes } \\
\text { S. aureus }\end{array}$ & $10.67 \pm 0.47$ & $8.67 \pm 0.47$ & $12.67 \pm 0.47$ \\
S. & $11.67 \pm 0.47$ & $9.33 \pm 0.47$ & $9.33 \pm 0.47$ \\
epidermidis & $10.67 \pm 0.47$ & $8.33 \pm 0.47$ & $11.33 \pm 0.47$ \\
$\begin{array}{l}\text { P. } \\
\text { aeruginosa }\end{array}$ & $0.00 \pm 0.00$ & $0.00 \pm 0.00$ & $10.67 \pm 0.47$ \\
$\begin{array}{l}\text { E. coli } \\
\text { B. subtilis }\end{array}$ & $9.33 \pm 0.47$ & $0.00 \pm 0.00$ & $9.33 \pm 0.47$ \\
\hline & $15.67 \pm 0.47$ & $0.00 \pm 0.00$ & $9.33 \pm 0.47$ \\
\hline
\end{tabular}

Table 4. Antimicrobial susceptibility of acetonic extract of combinations against the bacterial isolates

\begin{tabular}{|c|c|c|c|c|}
\hline $\begin{array}{l}\text { Group code } \\
\text { Combination } \\
\text { group }\end{array}$ & $(C / A)$ & $\begin{array}{c}A \\
(C / S)\end{array}$ & $(A / S)$ & $\begin{array}{c}B \\
(C / A / S)\end{array}$ \\
\hline Bacterial strain & Mean $\pm S D^{*}$ & Mean $\pm S D$ & Mean $\pm S D$ & Mean $\pm S D$ \\
\hline P. acnes & $14.67 \pm 0.47$ & $11.67 \pm 0.47$ & $10.67 \pm 0.47$ & $13.67 \pm 0.47$ \\
\hline S. aureus & $15.67 \pm 0.47$ & $10.33 \pm 0.47$ & $9.33 \pm 0.47$ & $11.33 \pm 0.47$ \\
\hline S. epidermidis & $18.67 \pm 0.47$ & $10.33 \pm 0.47$ & $11.33 \pm 0.47$ & $13.67 \pm 0.47$ \\
\hline P. aeruginosa & $16.67 \pm 0.00$ & $0.00 \pm 0.00$ & $10.67 \pm 0.47$ & $8.67 \pm 0.47$ \\
\hline E. coli & $20 . .33 \pm 0.47$ & $0.00 \pm 0.00$ & $9.33 \pm 0.47$ & $10.33 \pm 0.47$ \\
\hline B. subtilis & $15.67 \pm 0.47$ & $0.00 \pm 0.00$ & $9.33 \pm 0.47$ & $12.67 \pm 0.47$ \\
\hline
\end{tabular}

Combination group: C: Camellia sinensis; A: Azadirachta indica; S: Cassia acutifolia; Results were expressed as mean \pm SD 
possessed anti-bacterial activities against selected multi-drug resistant clinical and soil bacterial strains (Naveed et al., 2013).

The antibacterial susceptibility of plant extract combination $A(C / A)$ against bacterial strains was higher than other combination groups. To our knowledge, probably this is the first report to try the combination of Camellia sinensis and Azadirachtaindica experiment. One way ANOVA Tukey test was utilized and results showed in Table 5 illustrates the grouping information using Tukey method with $95 \%$ confidence interval. The $p$-value was $<0.001$ highly significant.

Statistical analysis showed the pairwise comparisons indicate that combinations of medicinal plants are not significantly different as they share the same grouping of " $A$ ". While combinations $A / S$ and $C / S$ were not significantly different as well since grouping " $\mathrm{B}$ " was shared.
But if the comparison were made, between C/A and $A / S$, the two combinations are significantly different; because they do not share common a letter as shown in Fig. 1. However; it is very clear that combination C/A was superior in terms of antibacterial susceptibility when compared with other combinations. Therefore; C/A was the best candidate as an antimicrobial agent.

\section{Determination of the Minimum Inhibitory} Concentration of the combination A (C/A)

MIC was recorded as the lowest concentration of the extract at which visible bacterial growth was completely inhibited. The experiment was performed in triplicate. MIC of combination $\mathrm{A}$ of medicinal plant extract against bacterial strains was determined using disc diffusion method assay. The highest concentration of combination possible to test was $8 \mathrm{mg} / \mu \mathrm{l}$ considered as MIC of antibacterial agent.

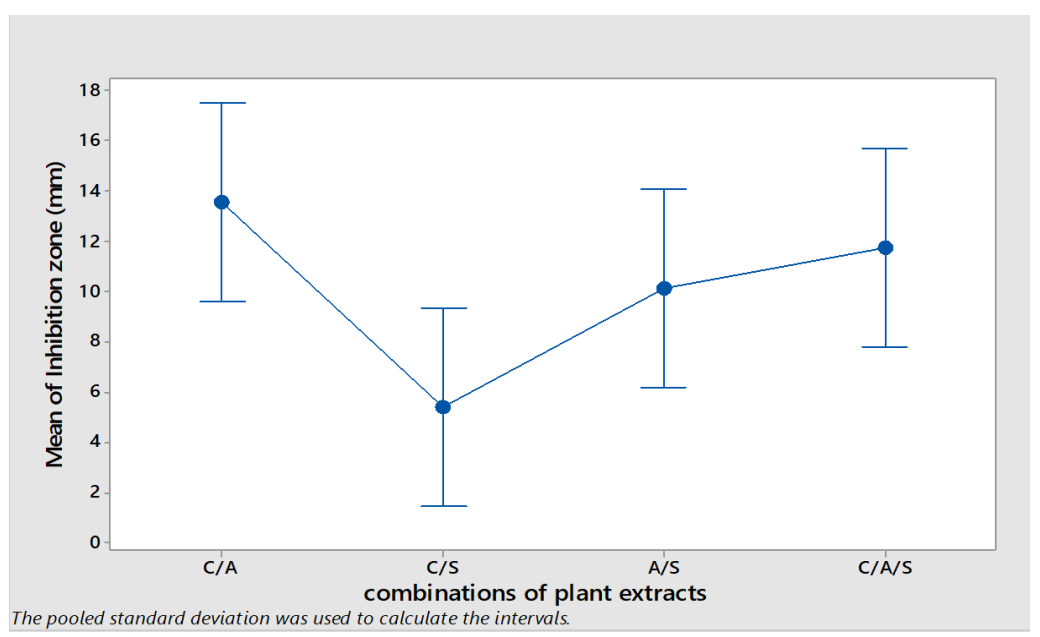

Fig. 1. The antibacterial susceptibility of combination of plant extract combination with $95 \%$ confidence intervals (Cl) for the mean. C/A: combination of Camellia sinensis with Azadirachta indica; C/S: combined with Camellia sinensis and Cassia acutifolia; A/S: combined with Azadirachta indica and Cassia acutifolia; C/A/S: combinations of all three medicinal plant together Camellia sinensis, Azadirachta indica and Cassia acutifolia.

Table 5. Tukey Pairwise Comparison of antibacteria susceptibility of combined action of plant extracts at p-value 0.001 against bacterial strains

\begin{tabular}{lcc}
\hline $\begin{array}{l}\text { Combination } \\
\text { Factor }\end{array}$ & Mean & Grouping \\
\hline C/A & 13.56 & A \\
C/A/S & 11.72 & A \\
A/S & 7.11 & B \\
C/S & 5.39 & B
\end{tabular}

\section{CONCLUSION}

The acetone extracts of the medicinal plant in our study (C, A, and S) showed the higher mean of antibacterial susceptibility against bacterial isolates. The acetonic extract of combinations of medicinal plants $A(C / A)$ showed high antibacterial susceptibility against bacterial isolates. The combination C/A was superior in terms of antimicrobial susceptibility when compared with other combination groups. 
It has successfully improved the antimicrobial susceptibility against bacterial isolates. Overall, it is concluded that the acetonic extract of $C / A$ was the best antibacterial agent candidate to treat acne vulgaris diseases. Further trials might confirm its best possible doses for a prescription to the dermatologists, physicians and, clinicians for the benefits of patients in the field.

\section{ACKNOWLEDGMENTS}

All authors are thankful to the Medical Laboratory Techniques Department Al-hawija Technical Institute, Northern Technical University, for providing all the facilities for this research work.

\section{CONFLICT OF INTEREST}

The authors declare that there is no conflict of interest.

\section{AUTHOR'S CONTRIBUTION}

All authors listed have made a substantial, direct and intellectual contribution to the work, and approved it for publication.

\section{FUNDING}

None.

\section{DATA AVAILABILITY}

All datasets generated or analyzed during this study are included in the manuscript.

\section{ETHICS STATEMENT}

This article does not contain any studies with human participants or animals performed by any of the authors.

\section{REFERENCES}

1. Abdullah-Al-Emran S.M., Ahmed Farzana, Saha, Sajal Kumar Das, Sreedam Chandra and Bachar Sitesh Chandra. Evaluation of Brine shrimp lethality and Antimicrobial activity of Azadirachta indica leaf extract on some drug resistance bacteria in Bangladesh. Pharmacognosy Journal, 2011; 3(20): 66-71(20).

2. Ali Muna Jalal, and Makky Essam A. Oral Health Care Improvement using Combined Toothpaste with Traditional Medicinal Plants. Advances in Environmental Biology, 2016; 10(7): 315-321.

3. Ali Muna Jalal, Makky Essam A. Batool, Tahira and Yusoff M. Susceptibility of oral bacteria to antimicrobial agents and virulence factors. Journal of
Chemical and Pharmaceutical Research, 2015 7(3): 1822-1829.

4. Aneja Kamal Rai, and Sharma Chetan. A timicrobial pote tial of fruit extracts of Elettaria cardamomum mato (chhoti elaichi) against the pathogens causing ear infection. Pharmacology online, 2010; 3: 750-756.

5. Choi Jae-Suk, Bae Hee-Jung, Kim Sung-Jo and Choi In Soon. In vitro antibacterial and anti-inflammatory properties of seaweed extracts against acne inducing bacteria, Propionibacterium acnes. Journal of environmental biology, 2011; 32(3): 313.

6. Donaldson Jack R., Warner Steven L., Cates Rex G. and Gary Young D. Assessment of antimicrobial activity of fourteen essential oils when using dilution and diffusion methods. Pharmaceutical biology, 2005; 43(8): 687-695.

7. Gahlaut Anjum and Chhillar Anil K. Evaluation of antibacterial potential of plant extracts using resazurin based microtiter dilution assay. International Journal of Pharmacy and Pharmaceutical Sciences, 2013; 5(2): 372-376.

8. Gupta Divya, and Kumar Mukesh. Evaluation of in vitro antimicrobial potential and GC-MS analysis of Camellia sinensis and Terminalia arjuna. Biotechnology Reports, 2017; 13: 19-25.

9. Kim Ji-Hoon, Yu Daeung, Eom Sung-Hwan, Kim Song-Hee, Oh Junghwan, Jung Won Kyo. Synergistic antibacterial effects of chitosan-caffeic acid conjugate against antibiotic-resistant acne-related bacteria. Marine drugs, 2017; 15(6): 167.

10. Mccutcheon A.R., Ellis S.M., Hancock R.E.W., and Towers G.H.N. Antifungal screening of medicinal plants of British Columbian native peoples. Journal of ethnopharmacology, 1994; 44(3): 157-169.

11. Mickymaray Suresh, Al-Aboody, Mohammad Saleh, Rath Pradipta Kumar, Annamalai, Panneerselvam and Nooruddin, Thajuddin. Screening and antibacterial efficacy of selected Indian medicinal plants. Asian Pacific Journal of Tropical Biomedicine, 2016; 6(3): 185-191.

12. Mukhtar Sana and Ghori Ifra. Antibacterial activity of aqueous and ethanolic extracts of garlic, cinnamon and turmeric against Escherichia coli ATCC 25922 and Bacillus subtilis DSm 3256. Int. J. Appl. Biol. Pharm. Technol., 2012; 3(2): 131-136.

13. Naveed, Rasheeha, Hussain, Iftikhar, Tawab, Abdul, Tariq, Muhammad, Rahman, Moazur, Hameed, Sohail. Antimicrobial activity of the bioactive components of essential oils from Pakistani spices against Salmonella and other multi-drug resistant bacteria. BMC complementary and alternative medicine, 2013; 13(1): 265.

14. Vora Jaykant, Srivastava Anshu and Modi Hashmukh. Antibacterial and antioxidant strategies for acne treatment through plant extracts. Informatics in Medicine Unlocked. 2017.

15. WHO. Traditional Medicines. J World Health Organization 2002-2005.2002. 